Gerencsér Péter

\title{
Észak-amerikai anzix?
}

\section{Lichter Péter: A láthatatlan birodalom. Írások a kísérleti filmr?l}

\section{Szerzó}

Gerencsér Péter 2017-ben szerzett doktori fokozatot a Szegedi Tudományegyetem Irodalomtudományi Iskolájában. Kutatási területei: internetes múvészet, újmédia, cseh/szlovák film, közép-európai animációs film. 


\section{Gerencsér Péter}

\section{Észak-amerikai anzix?}

\section{Lichter Péter: A láthatatlan birodalom. Írások a kísérleti filmr?l}

[Lichter Péter: A láthatatlan birodalom. Írások a kisérleti filmról. Budapest, Tudással a Jövőért Közhasznú Alapítvány, 2016. 175 oldal. (Prizma Könyvek 2.)]

Mérsékelt, ha nem éppen teljes csúsztatás volna annak kijelentése, hogy a magyar filmtörténeti recepció elhalmoz minket az avantgárd / kísérleti / underground film (a rokonszenvesebb szó képzeletben aláhúzandó) magyar szakirodalmának bőségével. Dacára annak, hogy mindkét nemzetközileg jelentôs, klasszikus filmteoretikusunk, Hevesy Iván és Balázs Béla egykorú írásai egyaránt bensôséges kapcsolatot ápoltak az avantgárd múvészettel - és annak részeként a filmes avantgárddal -, szerény a témát magyar nyelven, összefoglaló módon áttekintô publikációk száma.

Ami az alkotói oldalt illeti, ennek a fogadtatástörténeti hiányosságnak egyik magyarázata alighanem abban keresendô, hogy az 1920-30-as években a magyar filmtörténet lényegében kimaradt az európai avantgárd nemzetközi tendenciáiból, legfeljebb nagyon szúk keretek közé szorított stiláris hasonlóságokról beszélhetünk. Másrészt a kultúrpolitikai miliô sohasem kedvezett az avantgárd, majd évtizedekkel késôbb a neoavantgárd hazai kulturális integrációjának. Ennek következtében Huszárik Zoltán 60-as években készült kísérleti rövidfilmjei, majd azt követôen a magyar neoavantgárd film triumvirátusának (Bódy Gábor, Erdély Miklós, Jeles András) múvei belsô elôzmények nélkül, és szinte légüres térben voltak kénytelenek megszületni. ${ }^{[1]}$ Ugyanakkor még Huszárik experimentális munkáit is csak formai, és nem politikai-társadalmi értelemben lehetséges progresszívnek titulálni, mivel a tradicionálisnak vélt értékek védelmezésével és a jövô elutasításával olyan retrográd ideológia áll mögötte, mint amilyet az irodalomban a képzettársításaival radikális, ámde a múltba pátoszos módon beleragadt Nagy László versek képviseltek.

Ami pedig a filmtudományi recepciót illeti, Beke László és Peternák Miklós szétszórt, a társadalmi nyilvánosság peremén vagy az úgynevezett „második nyilvánosságban” megjelent írásait leszámítva, ha nem csalódom, csak egyetlen hazai szerzôtól származó kiadvány vállalkozott arra, hogy az európai filmes avantgárd tendenciáit magyar nyelven a teljesség igényével összefoglalja. Ez a munka a publikációs tilalommal nem feltétlenül sújtott Nemes Károly $A$ filmmúvészet kisérletezó irányzatainak szerepe a filmmüvészeti realizmus megteremtésében címú könyve, amely nemzeti alapon felosztva (német avantgárd, francia avantgárd, szovjet montázsiskola, amerikai experimentalizmus) vizsgál egy alapvetôen nemzetközi, sốt transznacionális filmes korpuszt. ${ }^{[2]}$ Bár az, hogy Nemes a kísérleti filmet olyan segédeszközként fogja fel, mint amely laboratóriumi 
körülmények között még be nem vezetett formanyelvi elemeket tesz próbára a realistának nevezett film számára, elsô pillantásra naivnak tûnhet, jobban belegondolva már kevésbé, mert egy olyan fontos tendenciára világít rá, amely általánosítható módon a múvészeti elitizmus partikularizmusa felôl a szélesebb közönségre igényt tartó tömegfilm irányába mutat.

A fentiekben csak nagyon sarkítva felvázolt, részint megkésett, részint sporadikus, részint pedig számos vonatkozásban féloldalas alakulástörténet - melynek hatásai meggyôzôdésem szerint máig kitapinthatóak a magyar filmkultúrában - határozza meg az avantgárd film produktív és receptív deficitjeit a magyar diskurzusban. Ezért is üdvözlendô Lichter Péternek a „kísérleti film” kiterjedt korpuszára fókuszáló könyve, mely ennek a recepciótörténeti lyuknak kortárs szemszögból való befoltozására vállalkozik. Önmagában is erénynek tekinthetô, hogy ezzel a mostohán kezelt vagy a címmel szólva: láthatatlan - filmes kategóriával egy filmtörténész önálló kötetben foglalkozik, mely alighanem a téma meghatározó hazai irodalma lesz. Tekintettel arra, hogy a szerző gyakorló filmkészító is, tárgyára nem pusztán a vonatkozó szakirodalmak felól, hanem alkotói szemmel is ráláthatott. A szerzô $A$ láthatatlan birodalom. Írások a kisérleti filmról címú munkájában zömmel az általa szerkesztett Prizma és a Filmvilág címú filmmúvészeti folyóiratokban korábban megjelent tanulmányait gereblyézte össze, azaz kiterjedt kutatói-oktatói munka áll mögötte.

Ez a fajta gyüjteményes megoldás azonban kevésbé képes számot vetni a tanulmány és a könyv közötti múfaji-mediális különbségekkel, melynek következtében Lichter múve nem minden esetben nélkülözi a koherenciaproblémákat. Noha a szerző sehol sem állítja könyvében, hogy az itt egybegyüjtött szövegek egymásból logikailag szorosan következő, folytonosan olvasható szövegek volnának, melyeket egyetlen szigorúan betartott vezérelv vagy tézis kovácsolna össze, az önmagukban is megálló egyedi tanulmányok hermeneutikailag mégis csak más megközelítésmódot igényelnek könyvformátumban, mert a befogadó a lineáris olvasás során az elôzmények ismeretében konstruálja meg későbbi előfeltevéseit és elvárásait. Az eredetileg különálló módon megjelentetett esszék effajta összeállítása az olvasónak (legalábbis nekem) gyakorta tûnik fragmentált szerkezetûnek, egyes gondolatok pedig olyan búvópatakra emlékeztetnek, melyek hirtelen eltúnnek a befogadó szeme elól, és a könyv más részein bukkannak a felszínre megint. Az alábbiakban - a könyvnek a „kísérleti film” hazai recepciójának gazdagításában és a tátongó ürök kitöltésében kijelölhetô erényeit szem elôtt tartva - három nagyobb problémahalmaz köré csoportosítom megjegyzéseimet. Elôször a fogalmi hálóra koncentrálok, ezt követôen a rendezôelvet veszem górcsô alá, végezetül pedig az avantgárd film módszertani megközelítését a nemzetközi szakirodalom felól vizsgálom. 


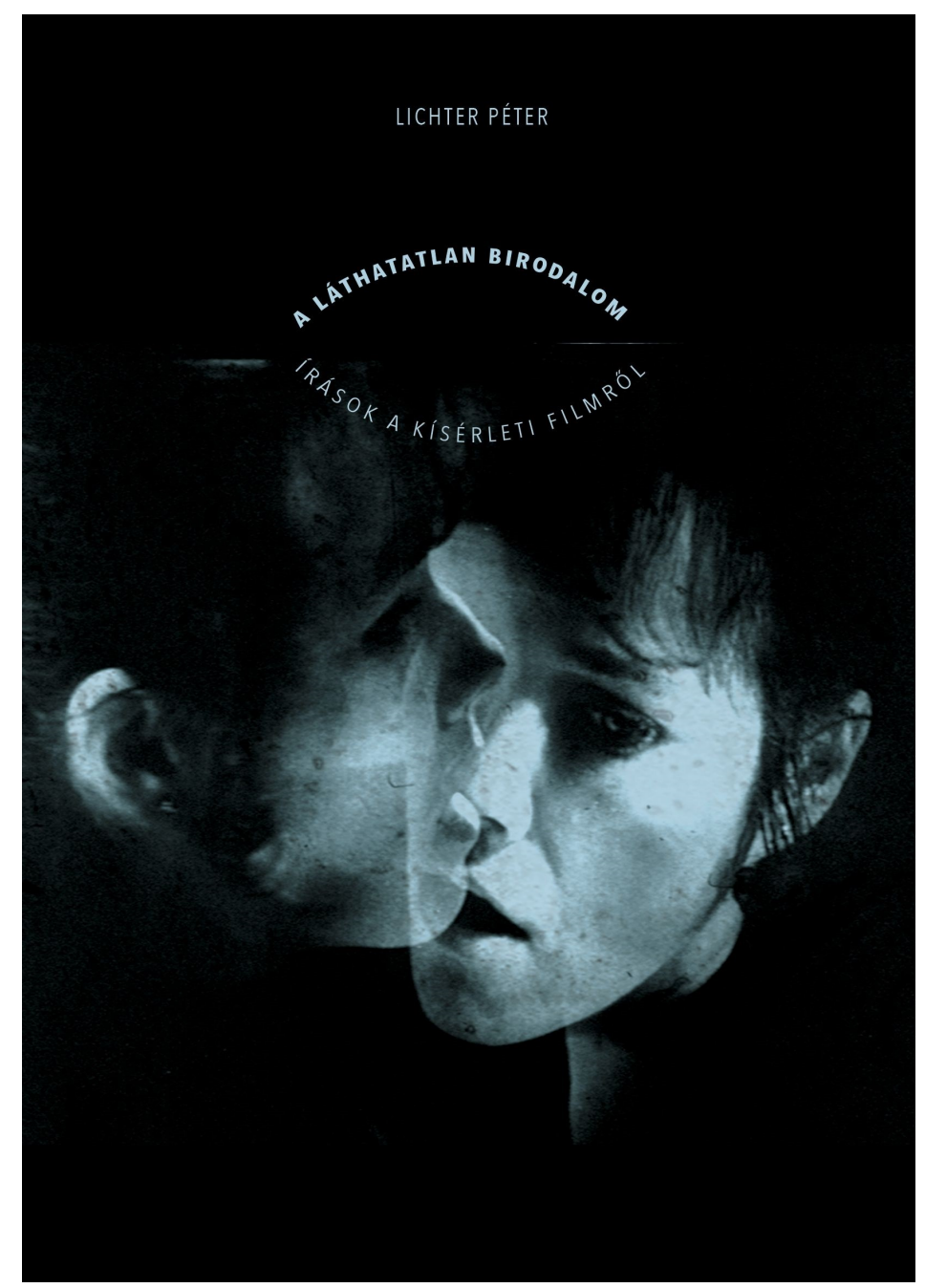

Lichter Péter: A láthatatlan birodalom. Írások a kísérleti filmról

\section{Fogalmi szövevények}

Avantgárd, kísérleti, underground, non-narrativ, absztrakt, nonfigurativ - hozzávetőlegesen a felsorolt terminusok képezik azt a fogalmi szövedéket, melyet a múvészet- és filmtörténeti diskurzus gyakran reflektálatlanul egymás szinonimájaként használ tárgyának leírásához. Lichter Péter könyvét semmiképpen nem érheti az a vád, hogy ezeknek a címkéknek az eltérô használati módjaihoz ne viszonyulna kritikusan, sokrétúen járja körül a szomszédos fogalmakat. Fontos, hogy kitér a köztük lévô különbségekre, érzékenyen elemzi azok elófeltevéseit, mégis helyenként ellentmondásos következtetésre jut.

A tanulmánykötet az alcímében a sokféle rivális fogalom közül a „kísérletit” tünteti ki domináns pozícióval (Írások a kísérleti filmról), amivel azt sugallja, hogy azt valamilyen szempontból relevánsabbnak látja a többinél. A kötet elsô tanulmánya azonban megtorpedózza ezt az olvasói hipotézist, amikor az elsó oldalakon azt olvashatjuk, hogy az underground kifejezéssel együtt a kísérleti is „mindenképpen megtévesztô, terminológiailag nem pontos kifejezések” (7 - a továbbiakban a zárójelben lévó számok pontos bibliográfiai hivatkozás nélkül is a könyv 
oldalszámaira vonatkoznak). A szerző roppant lényeges paradoxonra hívja fel a figyelmet, amikor a kisérletit a tudományos világból importált kifejezésként tárgyalja, és annak értelmezési tartományát - lévén, hogy minden film kísérleti - megszelídíthetetlennek ítéli (7-8.). Zavarba ejtô viszont, hogy a Bevezetés elsô mondataiban ezt olvassuk: „az avantgárd film - maradva ennél a jobban múködô, kevésbé félreérthetô terminusnál [...]” (7). Az olvasó itt kissé elveszíti orientációs pontjait a fogalmak használatát illetôen. Nem egészen világos számomra, hogy ha Lichter Péter szerint az avantgárd kifejezés ,jobban múködik”, a kisérleti pedig „mindenképpen megtévesztô”, miért a kisérletit választotta könyve alcímének. Természetesen tisztában vagyok vele, hogy mind az experimentális (kísérleti) film, mind pedig az avantgárd film fogalmai használatosak a filmtörténeti diskurzusban, és ezeknek a fogalmaknak a szabatos definíciója alighanem merő ábránd. Nem is kérem számon ezt a szerzô fogalomhasználatán, csupán az nincsen kellóképpen megvilágítva, hogy ha szerinte valamelyik ,jobban múködik", akkor miért nem azt használja, mivel a címválasztásokban paradox módon éppen ô utasítja el a ,jobbnak” gondolt avantgárd kifejezést. A másik két fogalom közül Lichter Péter az avantgárd kifejezés punktuális, befejezett jellegét sugalmazza, amikor arról értekezik, hogy „az »avantgárd « mint kifejezés anakronisztikussá vált mára" (7 - amiben burkoltan benne rejlik, hogy a terminus ezek szerint mégsem annyira „jobb”), néhány oldallal késóbb viszont már azzal a szövegrésszel találkozhatunk, hogy „az avantgárd film mindettôl függetlenül virágkorát éli” (10). A harmadik terminust, melyet Lichter konnotatív megkülönböztetésként alkalmaz, az underground képezi, melyet késôbbi keltezésûnek tart, és gyökereit „a hatvanas évek ellenkultúrájának felforgató, lázadó törekvéseiben” (8) keresi.

A terminológia útvesztôi között Lichter kétségtelenül nincsen könnyú helyzetben, mégis sikeresen mutat rá azok árnyalatnyi különbségeire és implikációira. Ahelyett, hogy megpróbálnánk az avantgárd, a kisérleti és az underground terminusoknak örökérvényú, minden próbát kiálló és pontos definíciót adni, érdemes ezeknek a fogalmaknak helyi értékeket tulajdonítani, és egy viszonyrendszer szövevényei között elhelyezni őket. A fogalmi háló kidolgozásánál véleményem szerint hasznos fogódzóként szolgált volna Havasréti Józsefnek az ellenkultúra fogalmával kapcsolatos okfejtése. Havasréti az underground kultúra, az ellenkultúra, az alternatív kultúra és a szubkultúra kifejezéseket a magyar neoavantgárd területén vizsgálva a következő konklúzióra jut:

$\mathrm{Az}$ »underground« és az »alternatív« kifejezések erôsen diskurzusfüggốk: nem annyira a társadalomtudományos beszédmód, mint inkább a kulturális, politikai, kritikai közbeszéd jellegzetes alkotóelemei. Egyrészt bármit jelenthetnek, másrészt inkább használják ôket elhatárolódásra és az identitás meghatározására, mintsem arra, hogy pontosan meghatározzanak vagy leírjanak velük különféle kulturális jelenségeket. ${ }^{[3]}$

Ezt a belátást kamatoztatva kérdéses, hogy mennyiben lehetséges az avantgárd, a kisérleti és az underground szavak jelentéseit normatív módon, kontextusaikból kiszakítva megzabolázni. Ezek a fogalmak inkább szélesebb értelemben vett „politikai” konnotációkkal bírnak, értékeik a helyzettôl függően változnak. A mindenkori domináns vagy intézményes kultúrával állnak szemben, azaz egy viszonyrendszer részeként ragadhatók meg. Mint majd a késóbbiekben visszatérek rá, a filmek 
formai jegyei mellett szükséges hangsúlyt fektetni azok kulturális-politikai környezeteire is, ahogyan Lichter Péter számos esetben vizsgálja ezt. Az avantgárd szó, abban az értelemben, ahogyan Lichter utal rá, minden kétséget kizáróan anakronisztikus, ha egy meghatározott idóbeli periódus mozgalmaként határozzuk meg, de ha az avantgárdot ahistorikus módon a fennálló (politikai, kulturális, esztétikai stb.) rendszer kritikájaként definiáljuk, akkor szükségszerúen eltûnő, de egyúttal újra is termelôdô attitúddel állunk szemben. Hadd illusztráljam ezt egy példával! Az amerikai médiateoretikus, Lev Manovich azt állítja, hogy az egykor avantgárdnak ítélt montázsesztétika és az Ember a felvevôgéppel (Dziga Vertov, 1929) formai kísérletei az 1980-as évek videoklipjeinek elfogadott elveivé váltak, utóbb pedig a digitális technikákban standardizálódtak.[4] Ezzel burkoltan azt is kijelenti, hogy ezek a technikák meg is szúntek avantgárdnak lenni, mert intézményesülésükkel elvesztették a domináns kultúrával szembeni potenciális kritikai lehetôségeiket (s itt visszautalnék Nemes Károly innen nézve már nem is feltétlen megmosolyogtató kísérletifilm-felfogására). Mindezek alaptapasztalata, hogy egy film avantgárd jellege diskurzusok közé ágyazva, nem pedig önmagában vizsgálható és érthetô meg.

Hasonló vonatkozik a kísérleti film és a történetnélküliség, valamint a vele kéz a kézben járó absztrakt film összefüggésére is. Lichter Péter afelé tereli az értelmezést, hogy az avantgárdként azonosított mozgóképi alkotásokhoz szorosan hozzátapad a non-narratív jelleg, az „avantgárd film ezzel szemben fittyet hányt a narratív múvészetre” (9), továbbá „a történetmesélés helyett a látványban rejlő lehetôségeket kereste" (11). Könnyedén lehetne persze érvelni ennek ellenkezője mellett, miszerint Wiene Caligarija és Bergman Personája, vagy éppen Alejandro Jodorowsky, Derek Jarman és Jan Švankmajer filmjei értelmezhetôk történetmesélôként is, de Lichter ezzel egy nagyon fontos összefüggésre utal. Az avantgárd filmek kétségtelenül hajlamosabbak mellôzni a narratívát - feltéve, ha a narratíva egzakt módon meghatározható, nem pedig egy széles skála fokozataiként gondolható el. Bevezetése egy adott pontján a szerzô egy mélyreható összefüggést állapít meg, amikor „az avantgárd filmeknek - a mainstreamhez képest[i] - a történetnélküliségérôl” beszél (8), de a filmavantgárd látványorientációjának - egyébként szintén lényeges - vizsgálata közepette kevésbé boncolgatja az avantgárd történetnélküliség fősodorhoz füződő viszonyának okait. Azt a kérdést, hogy az avantgárd filmek non-narratív természete olyan viszonyrendszerbe helyeződik, amely a domináns filmkultúrával áll szemben, részletesen vizsgálta viszont Malte Hagener. Az európai avantgárd film történetére fókuszáló Hagener arra az eredményre jutott, hogy az avantgárd film azért fonódik össze a non-narrativitással és az ezt kompenzáló absztrakcióval, mert a hollywoodi filmmel mint uralkodó filmkultúrával igyekezett polemizálni. ${ }^{[5]}$ Hagener megfogalmazásában: „[a]z elbeszélés kérdése, amely összekapcsolódott a mainstream filmiparral való szembenállással, a realizmus és az absztrakció körüli effajta vitában bizonyult vitatott pontnak". ${ }^{[6]}$ Vagyis az avantgárd film és az absztrakció házassága szerinte nem abban leli magyarázatát, hogy a történet úgyszólván kevésbé volna avantgárd, míg az absztrakt formák meg „avantgárdabbak” lennének, hanem azzal indokolható, hogy az avantgárd film a hollywoodi mainstream filmmel állt szemben, amely történetesen elbeszélő és „realista” volt. Mindez párhuzamba állítható Havasréti meglátásaival, melynek alapján egyes formai jegyek nem önmagukban, hanem kontextusaikban nyerik el értelmüket, és a non-narrativitás inkább politikai 
(ellenálló) cselekvés, mintsem eleve adott avantgárd formai sajátosság.

Végezetül pedig röviden az absztrakt film fogalmának ellentmondásairól. A szerzô lényegbevágó módon az avantgárd film alapvetô ismérveként azonosítja az absztrakciót, amelyrôl többek között azt állítja, hogy „eleve tagadja az ábrázolást” (18), az „absztrakt film »értelme« tehát éppen a jelentésnélküliségben, a látványosságban, a tiszta vizualitásban keresendô” (19). Eltekintve attól, hogy szerintem a nem-ábrázolás önmagában még nem egyenlô a jelentésnélküliséggel, hanem mint azt Patrícia Castello-Branco éppen a tiszta vizualitás kapcsán kifejti - a képek zsigeri hatásáról van szó, ${ }^{[7]}$ ezt az elgondolást egy másik teoretikus megfigyeléssel egészíteném ki. Michael Cowan Walter Ruttmann absztraktnak (vagy abszolútnak) nevezett filmjei kapcsán arra a következtetésre jutott, hogy az 1920-30-as évek európai filmes avantgárdjának jelentôs része éppen a nonfigurativitás (az „abszolút formalizmus”) és a figurativitás (a „denotatív referencialitás") közötti tudatos játékra, a felismerhető figurák és azok formai elbizonytalanításának ingadozásaira épült, ahol az esztétikai élvezetet éppen ez a folytonos fluktuáció biztosította a nézô számára. ${ }^{[8]}$ Vagyis ezekben a filmekben a figurativitás inherensen, szimultán módon és elválaszthatatlanul magában foglalta a formai „absztrahálást” (értsd: a nonfigurativitást) is, és vice versa, ahogyan Ruttmann Der Sieger (A bajnok, 1922) címú reklámjában a nappá és gumiabronccsá váló körformáknál megfigyelhetô. Ezek a fogalmakban rejlô belsố ellentmondások arra is felhívják a figyelmet, hogy milyen megoldhatatlannak látszó kihívásokkal kellett megküzdenie Lichter Péternek.

\section{Önálló tanulmányokból fejezetek}

A szerzô jelentôs érdeme, hogy többségében olyan szerzốk életmúvével foglalkozik, akikrôl eddig roppant keveset lehetett olvasni magyar nyelven (ha egyáltalán), különösen ilyen széles megközelítésben és koncentrációban. Mint a fentiekben utaltam rá, a könyv helyenként megfigyelhetố rendezôelvi problémái abból fakadnak, hogy a benne szereplô szövegek eredetileg önálló tanulmányként jelentek meg. Ami egyedi szövegek esetében múködôképesnek bizonyul, az nem feltétlenül kompatibilis egy könyv esetében, nagyobb egység részeként. Ennek illusztrálására elsôként az avantgárd idôkezelésre koncentráló tanulmányt említeném, amely Peter Hutton filmjeinek formai elemzésével ér véget (106), hiányzik azonban az összegzés, a nagyobb perspektíva, így a szöveg ott szakad félbe, ahol az olvasó még várna valamit, a rész (egy szerzôi portré) diadalmaskodik az egész (az avantgárd időfelfogás) felett. Egy másik példa: az amerikai absztrakt film kapcsán röviden elôbukkan ugyan a német avantgárd egyik fố alakjának, Oskar Fischingernek John Whitneyre és Jordan Belsonra gyakorolt hatása (44), de csak másik fejezetekben kerül kifejtésre ennek az alapvetô esztétikai befolyásnak a jellege (81,162). Még ennél a szövegnél maradva, az olvasónak (ismételten: nekem) az a benyomása, hogy a tanulmányok határai néhány esetben nem ott képződnek meg, ahol logikailag indokoltak lennének, és a címek is túlterjeszkednek a megjelölt témán. A Molekulák és galaxisok fényei - A kaliforniai absztrakt film tendenciái címú fejezet valójában nemcsak az amerikai experimentális filmre koncentrál, hanem a német abszolút filmre (Hans Richter, Viking Eggeling, Oskar Fischinger) is vonatkozik, vagyis 
lényegében a tanulmány fele másról szól, mint amit a cím ígér. Természetesen annyiban legitimálható ez az eljárás, hogy a német absztrakt filmet a szerzố hatástörténeti szempontból, egyfajta elôzményként tárgyalja. Mint azonban imént Fischinger kapcsán említettem, a szerzô csak a könyv más részeiben tisztázza az összefüggéseket, de nem kerül szóba a közvetlen kapcsolat a fischingeri geometrikus avantgárd és a két Whitney (James és John) korai, Five Film Exercises (1940-1945) címú szárnypróbálgatásai között. ${ }^{[9]}$

Ezek mellett a tanulmányok sorrendiségét is lehetett volna másként megtervezni, mert nem minden esetben támogatják a lineáris olvasást. Az amerikai absztrakt filmrôl szóló fejezet után például a kortárs avantgárd filmre ugrunk (A megmaradt látható - A kortárs absztrakt film legjelentôsebb alakjai), az ezt követô tanulmány azonban ismét visszatér az idôben az 1960-70-es évek strukturalista-materiális filmjeire. A science-fiction múfajának az asztronómiai absztrakcióval való összefüggésére koncentráló $A$ kozmosz metaforái címú írás logikailag remekül passzolna a kaliforniai absztrakt filmrôl szóló szakaszt követô helyre, már csak annál fogva is, mert egy marginalizált magasmúvészeti gyakorlatnak a populáris film általi inkorporációját lehetne nyomon követni benne, ehelyett ez a szöveg a strukturalista film után következik. Némileg megbicsaklik a logika, amikor elóbb olvashatjuk a könyvben a Stan Brakhage katalizáló hatásáról szóló tanulmányt (A nyelven túli költészet - A kortárs lírai film Brakhage után), mint a róla szóló portrét (Retina-szimfóniák: Stan Brakhage), azaz az idôben és hatástörténetileg késóbbi tendenciákkal foglalkozó szöveg sorrendben megelôzi a korábbit. Ilyenfajta felcserélés figyelhetô meg abban is, hogy Thorsten Fleisch filmjeihez a felütést Peter Kubelka szolgáltatja (,a fiatal német kísérleti filmes Peter Kubelka tanítványa volt, akinek a markáns konceptualizmusa nyomot hagyott Fleisch munkásságán” - 56), ami azt feltételezi, hogy a befogadónak a már olvasottak alapján ismernie kellene az ô metrikus filmjeit. Ezzel szemben Kubelka portréja csak késóbb, és egy másik tanulmányban kerül szóba (65-67.), megbontva az elôzetes tudás és az arra épüló új ismeretek klasszikus rendezőelvét.

A kötetet alapjában véve az amerikai avantgárd rövidfilmes formái uralják, amely azt az érzést kelti az olvasóban, hogy a kísérleti film nagyban észak-amerikai hitbizomány. Csak a könyv második felének három tanulmánya fókuszál kimondottan az amerikai filmen kívüli világra. Az egyik az osztrák Peter Tscherkassky-re összpontosító A celluloid feszültsége, a másik az orosz csodabogár, Vlagyimir Kobrin munkásságát tengelyébe állító az Alvajárók szinháza, a harmadik pedig a berlini székhelyú OJOBOCA duóval foglalkozó „Egy bolha van a füled belsejében” címú írás. Az amerikai film felé való hangsúlyeltolódást nagymértékben indokolhatóvá teszi az a szerzôi magyarázat, mely szerint 1945 után a filmes avantgárd „az észak-amerikai sz[í]ntérre helyezte fôhadiszállását, így az amerikai avantgárd film lett a világ meghatározó ereje a filmnyelvi radikalizmus területén" (12), mégis az európai tendenciák véleményem szerint alulreprezentáltak maradnak. Miközben Lichter utal lényeglátó módon arra, hogy az „osztrák kísérleti film az európai avantgárd mozgalmak kitartó védőbástyájának számít a második világháború utáni filmmúvészetben" (121), Tscherkassky-nak szentel csupán önálló tanulmányt. Szívesen olvastam volna a kortárs osztrák experimentális film egyik vezető alakjáról, Virgil Widrichról is, annál is 
inkább, mivel az általa alkotott Copy Shop (2001), különösen pedig a Fast Film (2003) a found footage egyik kitüntetett darabja, amely irányzattal Lichter kiemelten foglalkozik. Steve F. Anderson ez utóbbi film kapcsán az újmédia technológiái felól szemlélve alkotta meg a „digitális analóg” fogalmát, melyrôl a következốt állítja:

Widrich elutasítja az egyszerú digitális kompozitálást, hogy a fáradságos munkával készített, nyomtatott, tépegetett és hajtogatott origamiszerú animációt részesítse elônyben, ami létezése bizonyításának részeként szolgál. Ez a mú lényegében meghazudtolja a digitális kalózkodás könnyedségérôl és egyszerúségérôl, valamint a szerzôi joggal védett anyagokat felhasználók kreativitásának hiányáról szóló kortárs diskurzusokat. [...] A Fast Film talán a legtöményebb példája a »digitális analógnak«, azon kevés, de növekvố számú múveknek, amelyek megkísérlik újragondolni a digitális reprezentáció alapfogalmait, olyasmit, ami még a legmúlékonyabb gyakorlatok anyagi hordozói esetében is figyelmet követel (saját fordításom - G. P.). ${ }^{[10]}$

Hasonlóképpen szívesen olvastam volna arról is, hogy a szerző szerint a kelet-európai múvészek mennyiben járulták hozzá az avantgárd tendenciák formálódásához, mivel ez a kérdés rendszerint alulreprezentált a filmes avantgárd egyetemes diskurzusaiban. Gondolok itt nonfiguratív és ábrázoló áramlatokra egyaránt, melyek közül többek között a lengyel Stefan és Franciszka Themerson, a szerb Slavko Vorkapić, az ukrán Maya Deren, a cseh Alexander Hammid, a lengyel Walerian Borowczyk, a szerb Dušan Makavejev, a cseh Jan Švankmajer, a litván Deimantas Narkevičius vagy az észt Ülo Pikkov neve említhetô meg, némelyük emigrációja önmagában tanulságos.

A kötet utolsó három szövegéból kettô számomra amiatt tûnik rendezôelvi szempontból problémásnak, mert megbontják a mú szerkezetének egységességét. Közülük a Szemorgona Avantgárd spiritualizmus Az élet fája cimú filmben címú tanulmány azért lóg ki a sorból, mivel Pálos Mátéval közösen született, és az elemzés módjainak és terjedelmének különbségei látható nyomot is hagytak rajta. Az utolsó fejezet, a Láthatatlan határsértések - Kerekasztal beszélgetés a kortárs magyar kisérleti film helyzetérôl pedig mind múfaját (lejegyzett beszélgetés), mind pedig tartalmát (a magyar experimentalizmus) tekintve szervetlen a többihez képest, mivel a könyv eddig a pontig magyarral nem, ehelyett nemzetközi tendenciákkal foglalkozott. Ez átvezet utolsó fejezetem témájához, Lichter munkájának személetmódjához és annak a nemzetközi kutatásokkal való összevetéséhez.

\section{Az avantgárd „az nem egy tánc!”}

Nem kizárólagosan, de Lichter Péter könyve módszertani szempontból döntôen formai elemzések és szerzôi portrék keretében igyekszik megragadni az avantgárd filmet. Amint korábban Lev Manovich kapcsán utaltam rá, az avantgárd avantgárdságát illetôen a formai-stiláris vizsgálat önmagában nem mindig mutatkozik elegendőnek, mivel az avantgárd az ellenszegülés terepe. Erre Lichter is felhívja a figyelmet: „a szubverzív, ellenálló pozíció nem veszett ki belôle; ebben 
ragadható meg leginkább a szellemisége" (15). Egyes technikák és formatörténeti ismérvek a késôbbiekben már nem képesek a fennálló kritikájára, például az MTV-s videoklipek vagy a hollywoodi filmek montázsszerkezetük, attraktív vagy szürreális vizuális stílusaik és absztrakt elemeik dacára nem azonosíthatók olyan avantgárdként, mint a történeti avantgárd filmalkotásai, inkább azok formáit lúgozzák ki, immár mellôzve a domináns kultúrával való szembenállást. Ezért a filmek szélesebb értelemben vett politikai kontextusát is szükséges vizsgálni, politika alatt itt most nem csupán azt értve, amit általában szokás, hanem a társadalmi, kulturális és esztétikai rendszerekhez fúződô politikai viszonyt is idesorolva. Emiatt a kortárs filmtörténet bizonyos szegmensei a kultúratudományhoz fordulnak segítségül, amely az avantgárdot nem pusztán formai jegyek kombinációjaként írja le, hanem a fókusztávolság megváltoztatásával az ellenszegülést kulturális-politikai gyakorlatként tárgyalja. Vagyis elgondolásuk szerint a formai elemzés ezen filmek avantgárd / kísérleti jellegéról viszonylag keveset képes önmagában elárulni. Az avantgárd „az nem egy tánc”, hanem attitûd, életérzés, lázadás, szubverzió (bár súlyos ellentmondásokkal terhelt). 
Kíváncsi lettem volna Lichter Péternek az ezekkel a kérdésekkel foglalkozó szakirodalmakhoz füződô kommentárjaira szélesebb reflexió keretében is. Többek között a német teoretikus, Peter Bürger klasszikus könyvét illetôen, aki $A z$ avantgárd elméletében nem egyes múalkotásokat vizsgál, pláne nem formai szinten, hanem gondolatmenetét a múvészet intézményének fogalma köré szervezi, és a múalkotás koronként változó státuszára kíváncsi. ${ }^{[11]}$ Bürger úgy ír az avantgárdról, hogy lényegében egyetlen múvet sem idéz, egyetlen múalkotást sem elemez, még csak megközelítőleg sem, hanem azok kontextusait vizsgálja. Hasonló szemlélet jellemzi Malte Hagener már idézett Moving Forward, Looking Back címú monográfiáját, amely oly módon beszél a két háború közötti avantgárd filmrôl, hogy lényegében alig ejt szót maguknak a filmeknek a tartalmáról. ${ }^{[12]}$ Ezzel szemben Hagener olyan kérdésekkel foglalkozik, mint az avantgárd apóriák részletes kimunkálása, a vetítési gyakorlatok, az intézményi háttér, a filmiparhoz való viszony, a publikációs gyakorlatok, a hálózati csomópontok, kulturális hierarchiák stb. Vagyis az avantgárd filmet nagyon széles alapon vizsgálja, nem pusztán formák történeteként. Lichternél szintén szó esik a fesztiválokról, a politikai kontextusról, a populáris filmes gyakorlatok és a perifériára szorított avantgárd filmmúvészet kapcsolódási pontjairól, de zömmel a formatörténeti metodológia van túlsúlyban. Még egyszer említve a már idézett példát: a szerzô világosan megfogalmazza, hogy a második világháborút követôen az avantgárd film gócpontja Európából Észak-Amerikába, azon belül is fơként Kaliforniába tevődött át (12), de ennek okait kevésbé boncolgatja. Ez a roppant lényeges kérdés viszont ugyanúgy az avantgárd vagy kísérleti film történetének részét képezi, még ha a válasz maguknak a filmeknek a tartalmából nem is kihámozható. Egyes vélemények szerint az avantgárd film - sốt: az avantgárd múvészet - 1940-es évekbeli (ideiglenes) európai mélyrepülésének magyarázata nemcsak abban rejlik, hogy számos múvész a politika és a háború miatt kénytelen volt áttelepülni az USA-ba (Maya Deren, Alexandr Hackenschmied, Oskar Fischinger, Jonas Mekas), hanem legalább ennyire fontos összetevô, hogy az avantgárd múvészet a politikai földindulásokkal és diktatúrákkal való összekapcsolódása miatt Európában átmenetileg diszkreditálódott.

Lichter Péter többször, ismétlődően, eltérô kontextusban tér vissza a látványorientáltság és az avantgárd rendkívül fontos viszonyára, melynek gyökerei Tom Gunning immár klasszikus attrakcióelméletéhez nyúlnak vissza. ${ }^{[13]}$ Éppen azonban e viszony fragmentált tárgyalásmódja teszi nehézkessé, hogy a kérdésre irányuló vizsgálatot egységében és számos oldalról megvilágítva láthassuk, jóllehet ez az avantgárd film kategóriájának alighanem egyik igen termékeny vitapontjaként szolgálhatna. Annál is inkább, mert izgalmas kísérletként Lichter több esetben tárgyalja a sci-fi filmes múfaj és az avantgárd múvészet kapcsolatát az úgynevezett „új Hollywood” összefüggésében, amit a recepció szintén mostohán kezelt. Vagyis a szerzô szemléletmódjának nagy erénye, hogy az avantgárd filmet nem kezeli önálló, elszigetelt kategóriaként, melyet éles szakadék választana el a populáris filmtôl, hanem hazai kontextusban úttörố módon vizsgálja, hogyan áramlott be az avantgárd a közönségfilmbe. Ezeket a kérdéseket, túl az egyedi filmeken, számos irányba lehet kitágítani, úgy mint az avantgárd film formai jegyeinek bekebelezése és intézményesítése a populáris filmipar által, az esztétikai funkció és a szórakoztatás viszonya, a 
múvészetnek az úgynevezett életbe való visszavezetése (ami Peter Bürger teóriájának áll a középpontjában), az elitkultúra és a tömegkultúra gazdasági-politikai aspektusai, az alternatív terjesztési módok, az avantgárd film technológiai és financiális hátterének kérdése a reklámok összefüggésében stb. Mindezek szélesebb perspektívát és módszertant igényelnek.

Röviden a kötet két elemére fókuszálnék ezen szélesebb, kultúratudományi megközelítés mellett érvelve. Elôször az avantgárd film és a spiritualitás összefüggésére koncentrálok, amely a könyv több pontján visszatérô kérdés. A szerző a 19. oldalon teszi a következô lényeges megállapítást: „Az absztrakt film eszmerendszere komoly átfedésben van a természeti népek, a keleti vallások vagy akár az okkultista misztikusok filozófiájával - ez ugyanígy elmondható a korszak amerikai festészetérôl, az absztrakt expresszionizmusról, illetve a minimalizmus késôbb kibontakozó ágáról is”. Ezt az összefüggést Lichter itt javarészt a látványorientáció, a gunningi attrakcióelmélet szempontjából tanulmányozza, de ugyanilyen releváns volna azok szélesebb múvészeti, kulturális és politikai összefüggésrendszere. Első pillantásra valóban meglepőnek tûnhet, hogy miközben a 20. század emblémája Isten halálának nietzscheiánus gondolata, aközben a matematikai absztrakció a filmes avantgárdban minduntalan a misztikával párosul. Mike King többek között ezt a kérdést vizsgálva arra a következtetésre jut, amit Lichter kevésbé érint, hogy a misztikus beállítottság és a geometriai racionalizmus egymást látszólag kizáró párosítása a szférák harmóniájának püthagoraszi matematikai elméletéig vezethetô vissza. ${ }^{[14]}$ Ezt beszédes módon érzékelteti John Whitney posztumusz, az interneten megvalósított Whitney Music Box címú Flashalapú alkotása, mely a zenei skálát a színek spektrumának felelteti meg. ${ }^{[15]}$ Ugyanakkor a misztikus beállítottság nem függetleníthetô Kandinszkij képzőmúvészetétôl és teoretikus megnyilatkozásaitól sem, ${ }^{[16]}$ mint ahogyan a 60 -as évek misztikus és asztronómiai avantgárdja, akár Whitney - Lichter által is elemzett - hibrid filmjeit, akár a 2001: Ürodüsszeiát (A Space Odyssey. Stanley Kubrick, 1968) nézzük, az ûrverseny politikai összefüggéseitól sem.

A másik példa, amit szélesebb kontextusban érdemes vizsgálni, az avantgárdnak a reklámhoz való viszonyát érinti, amire Lichter Derengó folyosók az ismeretlenbe - Avantgárd föcímek címú tanulmánya koncentrál. Ez a tanulmány azért is fontos, és egyszersmind hazai környezetben unikális, mert olyan lesajnált, alkalmazottnak tekintett múfajjal foglalkozik, amit a filmtörténet kevésbé tart érdemesnek vizsgálatra, így rendszerint kiesik annak látóköréből. Az avantgárd és a reklám ezen házasságát Malte Hagener „stratégiai konvergenciának” nevezi, s amellett érvel, hogy az avantgárd film piaci szerepét részint éppen a reklámban találta meg, mert ezeknek a filmeknek új formanyelvre és attrakciós esztétikára volt szükségük. ${ }^{[17]}$ Ezt a kérdéskört tágítja ki egy nemrég megjelent tanulmánykötet, amely „árva filmeknek” (orphan films) nevezi azokat a marginalizált, önállóan gyakran megállni nem is képes alkotásokat (reklámfilm, fócím, ipari film, videoklip), amelyekben az avantgárd filmesek elôszeretettel kísérletezhettek. ${ }^{[18]}$ Mindezek folytán az avantgárd filmek formai oldala sok esetben nehezen választható el az ipari-kereskedelmi mozgatórugók vizsgálatától.

A szerző meglehetôsen takarékosan bánik az avantgárd filmre vonatkozó magyar és nemzetközi szakirodalom idézésével és a rájuk való utalással. Ez azzal a vesztességgel jár, hogy így számos 
esetben kevésbé alakítható ki dialogikus viszony azokkal a kérdésekkel, melyek a filmtörténeti diskurzust dominálják. Elvi szinten elképzelhetônek tartom ugyan, hogy úgy tárgyaljuk Oskar Fischinger vagy John Whitney munkásságát, hogy ne ejtsünk szót William Moritz nevérôl, ${ }^{[19]}$ de az ô mellôzöttségét nem feltétlenül ártana megindokolni. Miközben Lichter örvendetes módon hivatkozik a Moritz örökségébool kinövő Center for Visual Music alternatív filmmúvészeti archívumra (39, 10. lábjegyzet és 143), a vizuális zene terminusára csak egyetlen alkalommal hivatkozik (28), míg a vizuális szimfónia fogalmát, ha nem csalódom, nem említi, noha a tiszta vizualitásra (abszolút film / cinéma pur) irányuló avantgárd törekvések tekintélyes része írható le ezzel a fogalommal.

Könyvének koncepciója szerint Lichter Péter a kísérleti filmet zömmel a domináns filmkultúra melletti láthatatlan, alternatív filmtörténeti hagyományként reprezentálja, ami átvezet a mainstream és a periféria viszonyához. Ha nem tévedek nagyot a kötetcím szemantikáját illetôen, erre utal $A$ láthatatlan birodalom. Rendkívül lényeges azonban, hogy a szerzô kitér arra, hogy „az összetartozó szubkultúrák internetes hálózata nagyban segíti a múvek gyors terjedését” (10). Ez azonban úgy túnik, hogy a jelen perspektívájából vissza is vonja a könyv címének érvényességét, elvégre az avantgárd / kísérleti / underground / független / alternatív filmek - a terjesztés új, digitális és online módjainak hála - láthatókká váltak. Mindez felveti azt a kérdést, hogy az internetes terjesztés és a p2p fájlcseréló hálózatok korában lehetséges-e egyáltalán az underground és a láthatatlanság, és ha igen, akkor az a korábbiakhoz képest miben és hogyan változott meg. A szerző által felvetett problémát továbbgondolva egy fontos tanulmányra szeretném felhívni végül a figyelmet. Hito Steyerl $A$ silány kép védelmében szólva baloldali alapállásból az internetet olyan új lehetôségnek látja, amelynek révén kikerülhetô az intézményi monopólium, a kultúra áruként való felfogásának neoliberális kereskedelmi szemlélete, és amely a kísérleti filmek újfajta reneszánszát hozta el. A szerzô ebben a folyamatban a puszta terjesztésnél egy jóval jelentôsebb elmozdulást detektál:

A silány képek felbukkanása a Harmadik Film egyik klasszikus manifesztumára, Juan García Espinosa 1960-as évek végén Kubában írott $A$ tökéletlen filmért címúre emlékeztet. Espinosa azért érvelt a tökéletlen film mellett, mert - saját szavaival - »a tökéletes - a technikailag és múvészileg mesteri - film szinte mindig reakciós film«. A tökéletlen film az, ami arra törekszik, hogy felszámolja az osztálytársadalmon belüli munkamegosztást. Egyesíti a múvészetet az élettel és a tudománnyal, elmossa a fogyasztó és az alkotó, a közönség és a szerző közötti különbséget. Ragaszkodik saját tökéletlenségéhez, népszerú, de nem fogyasztói, anélkül elkötelezett, hogy bürokratikussá válna. [...] Miközben a silány képek területe a kirekesztett képekhez való hozzáférést teszi lehetôvé, azon közben a legfejlettebb értékesítési technikák is áthatják. Miközben a tartalom létrehozásában és terjesztésében lehetôvé teszi a felhasználók aktív részvételét, aközben az alkotásba is bevonja ôket. A felhasználók a silány képek szerkesztôi, kritikusai, fordítói és (társ)szerzői lesznek (saját fordításom - G. P.). ${ }^{[20]}$ 
Ebből a szempontból újragondolásra késztet minket, hogy a digitális átalakítás és terjesztés mennyiben értelmezi át a láthatatlanságot, melyet a könyv alcímének optikai metaforája sugall a kísérleti filmhez való hozzáférés kapcsán.

Ami pedig magát a könyvet illeti, Lichter Péter munkája bizonyosan nagyban hozzájárul e láthatatlan birodalom láthatóságához.

1. Peternák Miklós: A magyar avant-garde film. In Uô (szerk.): F. I. L. M. A magyar avant-garde film története és dokumentumai. Budapest, Képzômüvészeti, 1991. 25.

2. Nemes Károly: A filmmüvészet kisérletezổ irányzatainak szerepe a filmmüvészeti realizmus megteremtésében. Budapest, Kossuth, 1974.

3. Havasréti József: Alternatív regiszterek. A kulturális ellenállás formái a magyar neoavantgárdban. Budapest, Typotex, 2006. 28-29.

4. Manovich, Lev: Avant-garde as Software. Artnodes, 2002. https://www.uoc.edu/artnodes/espai/eng/art/manovich1002/manovich1002.html (utolsó letöltés dátuma: 2017-11-29)

5. Hagener, Malte: Moving Forward, Looking Back. The European Avant-Garde and the Invention of Film Culture 1919-1939. Amsterdam, Amsterdam University Press, 2007. 54-56.

6. Hagener: i.m. 56.

7. Castello-Branco, Patrícia: Tiszta érzékek? Az absztrakt filmtôl a digitális képekig. Ford. Gerencsér Péter. Apertúra, 2012. nyár URL: http://apertura.hu/2012/nyar/castello-branco-tiszta-erzekek-az-absztraktfilmtol-a-digitalis-kepekig

8. Cowan, Michael: Absolute Advertising: Walter Ruttman and the Weimar Advertising Film. Cinema Journal, 52. 2013/4. 53 .

9. Erról lásd Moritz, William: Optical Poetry: The Life and Work of Oskar Fischinger. Bloomington, Indiana University Press, 2004. 121.

10. Anderson, Steve F.: Aporias of Digital Avant-Garde. Digital Humanities Quarterly, 1. 2. (2007) , URL: http://digitalhumanities.org/dhq/vol/1/2/000011/000011.html (az utolsó letöltés dátuma: 2017-11-29)

11. Bürger, Peter: Az avantgárd elmélete. Ford. Seregi Tamás. Szeged, Universitas Szeged, 2010.

12. Hagener 2007.

13. Gunning, Tom: Az attrakció mozija. A korai film, nézője és az avantgárd. Ford. Kaposi Ildikó. In Kovács András Bálint - Vajdovich Györgyi (szerk.): A kortárs filmelmélet útjai. Budapest, Palatinus, 2004. 292-302.

14. King, Mike: Számítógépek és a modern müvészet. (A Digital Art Museum). Ford. Fellmann Barbara Rozália. Fosszilia, 2004/1. 107-121.

15. A projektet lásd: whitneymusicbox.org

16. Kandinszkij, Vaszilij: A szellemiség a müvészetben. Ford. Szántó Gábor András. Budapest, Corvina, 1987.

17. Hagener 2007: 35-36. A kérdést az animációs reklámok összefüggésében tárgyaltam: Gerencsér Péter: A Kiskakas elôtt. A korai magyar animációs reklámfilm transznacionális megközelítésben. Metropolis, 2015/3. 24-44.

18. Florin, Bo - de Klerk, Nico -Vonderau, Patrick (szerk.): Films that Sell: Moving Pictures and Advertising. London, Palgrave, 2016.

19. Moritz 2004.

20. Steyerl, Hito: In Defense of the Poor Image. E-Flux, 2009/11. URL: http://www.e-flux.com/journal/indefense-of-the-poor-image 


\section{Irodalomjegyzék}

- Anderson, Steve F.: Aporias of Digital Avant-Garde. Digital Humanities Quarterly, 1. 2. (2007) , URL: http://digitalhumanities.org/dhq/vol/1/2/000011/000011.html (az utolsó letöltés dátuma: 2017-11-29)

- Bürger, Peter: Az avantgárd elmélete. Ford. Seregi Tamás. Szeged, Universitas Szeged, 2010.

- Castello-Branco, Patrícia: Tiszta érzékek? Az absztrakt filmtôl a digitális képekig. Ford. Gerencsér Péter. Apertúra, 2012. nyár URL: http://apertura.hu/2012/nyar/castello-brancotiszta-erzekek-az-absztrakt-filmtol-a-digitalis-kepekig

- Cowan, Michael: Absolute Advertising: Walter Ruttman and the Weimar Advertising Film. Cinema Journal, 52. 2013/4. 49-73.

- Florin, Bo - de Klerk, Nico -Vonderau, Patrick (szerk.): Films that Sell: Moving Pictures and Advertising. London, Palgrave, 2016.

- Gerencsér Péter: A Kiskakas elôtt. A korai magyar animációs reklámfilm transznacionális megközelítésben. Metropolis, 2015/3. 24-44.

- Gunning, Tom: Az attrakció mozija. A korai film, nézője és az avantgárd. Ford. Kaposi Ildikó. In Kovács András Bálint - Vajdovich Györgyi (szerk.): A kortárs filmelmélet útjai. Budapest, Palatinus, 2004. 292-302.

- Hagener, Malte: Moving Forward, Looking Back. The European Avant-Garde and the Invention of Film Culture 1919-1939. Amsterdam, Amsterdam University Press, 2007.

- Havasréti József: Alternatív regiszterek. A kulturális ellenállás formái a magyar neoavantgárdban. Budapest, Typotex, 2006.

- Kandinszkij, Vaszilij: A szellemiség a múvészetben. Ford. Szántó Gábor András. Budapest, Corvina, 1987.

- King, Mike: Számítógépek és a modern múvészet. (A Digital Art Museum). Ford. Fellmann Barbara Rozália. Fosszília, 2004/1. 107-121.

- Lichter Péter: A láthatatlan birodalom. Irások a kísérleti filmrốl. Budapest, Tudással a Jövőért Közhasznú Alapítvány, 2016.

- Manovich, Lev: Avant-garde as Software. Artnodes, 2002. https://www.uoc.edu/artnodes/espai/eng/art/manovich1002/manovich1002.html (utolsó letöltés dátuma: 2017-11-29)

- Moritz, William: Optical Poetry: The Life and Work of Oskar Fischinger. Bloomington, Indiana University Press, 2004.

- Nemes Károly: A filmmúvészet kísérletezố irányzatainak szerepe a filmmüvészeti realizmus megteremtésében. Budapest, Kossuth, 1974.

- Peternák Miklós: A magyar avant-garde film. In Uó (szerk.): F. I. L. M. A magyar avant-garde film története és dokumentumai. Budapest, Képzőmúvészeti, 1991. 5-51.

- Steyerl, Hito: In Defense of the Poor Image. E-Flux, 2009/11. URL: http://www.eflux.com/journal/in-defense-of-the-poor-image (az utolsó letöltés dátuma: 2017-11-29.) 


\section{Filmográfia}

- Caligari (Das Cabinet des Dr. Caligari. Robert Wiene, 1920)

- Copy Shop (Virgil Widrich, 2001)

- Der Sieger (Walter Ruttmann, 1922)

- Ember a felvevốgéppel (Chelovek s kino-apparatom. Dziga Vertov, 1929)

- Fast Film (Virgil Widrich, 2003)

- Five Film Exercises (James Whitney, John Whitney, 1940-1945)

- Persona (Ingmar Bergman, 1966)

- 2001: Ürodüsszeia (2001: A Space Odyssey. Stanley Kubrick, 1968) 
(C) Apertúra, 2017. Ỗsz | www.apertura.hu

webcím: https://www.apertura.hu/2017/osz/gerencser-eszak-amerikai-anzix-lichter-peter-a-

lathatatlan-birodalom-irasok-a-kiserleti-filmrol/

https://doi.org/10.31176/apertura.2018.13.1.9

(Q)opertúro 